\title{
PERAN DINAS PARIWISATA DALAM TATA KELOLA PENGEMBANGAN WISATA PANTAI MAMPIE UNTUK MENINGKATKAN KESEJAHTERAAN MASYARAKAT DI KECAMATAN WONOMULYO DESA GALESO KABUPATEN POLEWALI MANDAR
}

\author{
Nama Penulis \\ ${ }^{1}$ Suci Rahma, ${ }^{2}$ H. Sjuaib hannan, ${ }^{3}$ Andriani \\ Ilmu pemerintahan Universitas Al Asyariah Mandar \\ Email: suciirahma522@gmail.com
}

\section{ABSTRACT}

Suci Rahma, 2021 "The Role of the Tourism Office in the Management of Mampie Beach Tourism Development to Improve Community Welfare in Wonomulyo District, Galeso Village, Polewali Mandar Regency" Supervised by Mr. H. Sjuaib Hannan as supervisor I and Mrs. Andriani as supervisor II

This study aims to determine the role of the tourism office in the management of Mampie beach tourism development to improve the welfare of the community in Galeso Village, Wonomulyo District, Polewali Mandar Regency. The role of the tourism office as a coach for the management of Mampie beach tourism which acts as a motivator, facilitator and dynamist in realizing an increase in visiting tourists and the welfare of the community around Mampie beach tourism. Therefore, with the role of the tourism office which is directly optimal and deep to build the community.

The type of research used is qualitative research with a quantitative approach where data is obtained through observation, interviews and documentation. The informants in this study were fifteen people including the Head of the Youth, Sports and Tourism Office of Polewali Mandar Regency, the Head of Business and Tourism, the Head of Galeso Village, Wonomulyo District and the Head of Kopdarwis (tourism awareness group). The results of the study indicate that the Tourism Office carries out various information through social media. Increasing motivation by providing training to the community. The Tourism Office empowers the community around the mampie beach by providing direction and socialization.

Based on the results of the research that has been done, it can be seen that in the development of the tourism sector in Mampie Beach, the Polewali Mandar Regency Tourism Office has done quite optimally. Judging from his role as the coordinator of the Polewali Mandar Regency Tourism Office in promoting tourism by carrying out the development, 
coaching and preservation of Mampie Beach tourism. The socialization was carried out to the community to open up understanding and the mindset of the community that the importance of preserving Mampie Beach tourism.

\section{ABSTRAK}

Suci Rahma, 2021 "Peran Dinas Pariwisata Dalam Tata Kelola Pengembangan Wisata Pantai Mampie Untuk Meningkatkan Kesejahteraan Masyarakat Di Kecamatan Wonomulyo Desa Galeso Kabupaten Polewali Mandar" Di bimbing oleh Bapak H. Sjuaib Hannan selaku pembimbing I dan Ibu Andriani selaku pembimbing II

Penelitian ini bertujuan untuk mengetahui peran dinas pariwisata dalam tata kelola pengembangan wisata pantai mampie untuk meningkatkan kesejahteraan masyarakat di Desa Galeso Kecamatan Wonomulyo Kabupaten Polewali Mandar. Peran dinas pariwisata sebagai pembina pengelola wisata pantai mampie yang berperan sebagai motivator, fasilisator dan dinamisator dalam mewujudkan peningkatan wasatawan yang berkunjung serta mensejahterakan masyarakat disekitar wisata pantai mampie. Maka dari itu dengan adanya peran dinas pariwisata yang secara langsung optimal dan mendalam untuk membangun masyarakat.

Jenis penelitian yang digunakan adalah penelitaian kualitatif dengan pendekatan kuantitatif dimana data yang diperoleh melalui observasi, wawancara dan dokumentasi. Adapun informan dalam penelitian ini sebanyak lima belas orang diantaranya Kepala Dinas Pemuda Olahraga dan Pariwisata Kabupaten Polewali Mandar, Kepala Bidang Usaha dan Pariwisata, Kepala Desa Galeso Kecamatan Wonomulyo dan Ketua Kopdarwis (kelompok sadar wisata). Hasil penelitian menujukan bahwa Dinas Pariwisata melakukan berbagai informasi melalui media sosial. Peningkatan motivasi dengan memberi pelatihan pada masyarakat. Dinas Pariwisata melakukan pemberdayaan kepada Masyarakat sekitar pantai mampie tersebut dengan memberikan arahan dan sosialisasi.

Berdasarkan hasil penelitian yang telah dilakukan dapat dilihat bahwa dalam pengembangan sektor wisata yang ada di Pantai Mampie, Dinas Pariwisata Kabupaten Polewali Mandar telah melakukan dengan cukup optimal. Dilihat dari perannya sebagai koordinator Dinas Pariwisata Kabupaten Polewali Mandar dalam mempromosikan wisata dengan melaksanakan Pengembangan, pembinaan dan pelestarian wisata Pantai Mampie .Sosialisasi yang dilakukan pada masyarakat untuk membuka pemahaman serta pola pikir masyarakat bahwa pentingnya upaya pelestarian wisata Pantai Mampie.

\section{KATA KUNCI : Peran,tata kelola, wisata Pantai}


Peran Dinas Pariwisata Dalam Tata Kelola Pengembangan Wisata Pantai Mampie Untuk Meningkatkan Kesejahteraan Masyarakat Di Kecamatan Wonomulyo Desa Galeso Kabupaten Polewali Mandar

\section{PENDAHULUAN}

Pariwisata merupakan aktivitas dinamis yang menyangkut tentang kehidupan manusia dari berbagai bidang usaha. Di era globalisasi pariwisata akan menjadi pendorong utama atau menjadi sektor perekonomian dunia dan menjadi industri mendunia. Pariwisata juga akan menjadi potensi yang besar terhadap sektor perekonomiannya. Bahkan pada masa globalisasi saat ini dibeberapa daerah yang sudah berkembang pesat telah menjadi cerminan wisatawan, walaupun hanya untuk menghabiskan waktu luang. Sehubungan dengan tata kelola pariwisata dalam pembangunan sebagaimana yang telah tercantum dalam UU Pemerintah Nomor 10 Tahun 2009 tentang kepariwisataan pasal 6 yang berbunyi: pembangunan kepariwisataan dilakukan berdasarkan asas sebagaimana yang dimaksud pasal 2 yang diwujudkan melalui pelaksanaan rencana pembangunan kepariwisataan dengan memperhatikan keaneka ragaman, keunikan, dan kekhasan budaya dan alam, serta kebutuhan manusia untuk berwisata. Atas dasar itu pula dengan melihat situasi dan kondisi saat ini "pariwisata dapat diartikan sebagai suatu perjalanan terencana yang dilakukan secara individu atau kelompok dari satu tempat ke tempat lain dengan tujuan untuk mendapatkan kepuasan dan kesenangan" (Sinaga, 2010:12). Tata kelola pantai merupakan kegiatan di tepi pantai yang dilakukan oleh orang dalam rangka meningkatkan manfaat sumber daya lahan ditinjau dari sudut lungkungan dan sosial ekonomi dengan cara pengurungan, pengeringan lahan, atau drainase. Tata kelola pantai merupakan kawasan hasil perluasan daerah pesisir pantai melalui rekayasa teknis untuk pengembangan kawasan baru.Tata kelola pantai termasuk dalam kategori kawasan yang terletak di tepi Pantai, dimana pertumbuhan dan perkembangannya baik secara sosial dan ekonomi. Pengelola wilayah pesisr pantai adalah suatu proses perencanaan, pemanfaatan, pengawasandan pengendalian sumber daya pesisir Pantai.

Tata kelola pantai merupakan kegiatan di tepi pantai yang dilakukan oleh orang dalam rangka meningkatkan manfaat sumber daya lahan ditinjau dari sudut lungkungan dan sosial ekonomi dengan cara pengurungan, pengeringan lahan, atau drainase. Tata kelola pantai merupakan kawasan hasil perluasan daerah pesisir pantai melalui rekayasa teknis untuk pengembangan kawasan baru.Tata kelola pantai termasuk dalam kategori kawasan yang terletak di tepi Pantai, dimana pertumbuhan dan perkembangannya baik secara sosial dan ekonomi. Pengelola wilayah pesisr pantai adalah suatu proses perencanaan, pemanfaatan, pengawasan dan pengendalian sumber daya pesisir Pantai.

Pembinaan serta pengembangan pariwisata yang dilakukan Dinas 
Pemuda Olahraga dan Pariwisata dengan memperhatikan dan memelihara wisata pantai Mampie kepribadian Nasional upaya yang dilakukan pemerintah dalam hal pengembangan pariwisata lebih ditujukkan kepada pengenalan budaya, bangsa dan tanah air, bidang promosi penyediaan fasilitas serta mutu dan kenyamanan pelayanan. Hal untuk mencapai kesuksesan dalan pengembangan pariwisata sangat diperlukan banyak pemahaman baik dari sisi pemerintah maupun dari sisi masyarakat. Pemerintah juga harus memerhatikan dan memastikan bahwapengembangan pariwisata akan mampu memberikan keuntungan atau bagi potensi di daerah tersebut sekaligus menekan biaya sosial dan ekonomi serta dampak dari lingkungan setempat. Disisi lain masyarakat sebagai pelaku wisata yang akan lebih terfokus pada arah keuntungan, tentu tidak semerta-merta melakukan apa saja demi mencapai sebuah keuntungan, tetapi harus juga berlandaskan dengan kebijakan yang dikeluarkan oleh pemerintah dalam pengembangan pariwisata. Pantai Mampie yang terletak di Desa Galeso memiliki luas 4.162 Ha.yang meskipun Pantai Mampie memiliki potensi yang besar sebagai daerah tujuan wisata, akan tetapi pada kenyataannya pantai mampie masih

Sejalan dengan persoalan objek wisata di Kabupaten Polewali mandar dalam usaha meningkatkan jumlah kunjungan wisatawan, maka keberadaan public relations pada Dinas pemuda olahraga dan pariwisata sangat diperlukan. Adanya bagian tersendiri yang khusus menangani masalah public relations akan lebih meningkatkan pelaksanaan komunikasi efektif yang akan mendukung pelaksanaan strategi promosi wisata Dinas pemuda olahraga dan pariwisata Kabupaten Polewali mandar.

\section{METODE PENELITIAN}

\section{A. Jenis Penelitian}

Penelitian ini merupakan jenis penelitian kualitatif, yaitu pemecah masalah yang diselidiki dengan menggambarkan atau melukiskan keadaan objek penelitian sekarang, berdasarkan fakta-fakta yang tampak atau sebagaimana adanya.Penggunaan metode ini dimulai dari analisis berbagai data yang dihimpun dari penelitian, kemudian bergerak kearah kesimpulan.Tujuan dari metode ini tidak semata-mata mengungkapkan kebenaran saja tetapi memahami kebenaran tersebut.

\section{B. Jenis dan Sumber Data}

Sumber data penelitian adalah kata-kata dan tindakan, selebihnya adalah tambahan seperti dokumen dan lain-lain. Berkaitan dengan ini jenis data dibagi dalam kata-kata dan tindakan atau disebut juga data 
Peran Dinas Pariwisata Dalam Tata Kelola Pengembangan Wisata Pantai Mampie Untuk Meningkatkan Kesejahteraan Masyarakat Di Kecamatan Wonomulyo Desa Galeso Kabupaten Polewali Mandar

primer dan sumber tertulis, foto, statistic, atau disebut juga data sekunder

1. Data primer

Data primer adalah data yang diperoleh dari data wawancara dari narasumber atau informan yang dianggap berpotensi dalam memeberikan informasi yang relevan dan sebenarnya dilapangan. Dalam penelitian ini, informan yang dijadikan sebagai sampel untuk diambil datanya adalah:

a. Dinas pariwisata terdiri dari kasubag perencanaan dan kasi. Pengembangan objek wisata.

b. Pemerintah desa terdiri dari kepala desa dan kasi. Kesejahteraan masyarakat.

c. Pengelola terdiri dari coordinator lapangan dan ketua pokdarwis.

d. Wisatawan yang dapat dijadikan sebagai informasi sebanyak dua orng.

Menurut Burhan Bungin (2006:53) berkenan dengan tujuan penelitian kualitatif, maka dalam prosedur sampling yang terpenting adalah bagaimana menentukan informasi kunci (key informan) atau situasi sosial tertentu yang syarat informasi sesuai dengan fokus penelitian. Bilamana dalam proses pengumpulan data sudah tidak lagi ditentukan variasi informasi, maka peneliti tidak perlu lagi untuk mencari informasi baru, proses pengumpulan informasi dianggap sudah selesai. Dengan demikian penelitian kualitatif tidak dipersoalkan jumlah sample. Dalam hal ini jumlah sampel atau informasi bisa sedikit tetapi juga bisa banyak tergantung dari tetapi tidaknya pemelihan informasi kunci dan kompleksitas dan keragaman fenomena sosial yang diteliti. Teknik sampel yang digunakan dalam penelitian adalah secara senagaja atau purposive sampling. Teknik purposive sampling merupakan penentuan sampel dengan pertimbangan tertentu.

\section{Data sekunder}

Data sekunder adalah data pendukung dan data primer dari literature dan dokumen serta data yang diambil dari suatu organisasi.Data sekunder dalam penelitian terdiri dari wisata Pantai Mampie Desa Galeso Kabupaten Polewali Mandar.

\section{Teknik Analisis Data}

Aktivitas dalam analisis data meliputi: data reduction (reduksi data), data display (penyajian data), danconclusion drawing verification (penarik kesimpulan). (Sugiyono,2007:337). 
berikut:

Langkah-langkah analisis data dalam penelitian ini jelas sebagai

1. Data Reduction (Reduksi Data).

Mereduksi data berarti merangkum, melalui hal-hal yang pokok, memfokuskan pada hal-hal yang penting, dicari tema, polanya, dan membuang yang tidak perlu. Dengan demikian data yang sudah direduksi akan memberikan gambaran yang lebih jelas, dan mempermudahkan penelitian untuk melakukan pengumpulkan data selanjutnya, dan mencarinya bila diperlukan.

2. Data display (Penyajian Data)

Penyajian data biasanya dalam bentuk uraian singkat, bagan,berhubungan antar kategori,flowchart dan jenisnya. Yang paling sering digunakan untuk menyajikan data, maka akanmemudahkan untuk memahami apa yang terjadi, merencanakan kerja selanjutnya, dan mencarinya bila perlu.

3. Conclusion Drawing Verification (penarik kesimpulan).

Langkah ketiga dalam analisis data kualitatif adalah penarikan kesimpulan dan verifikasi. Kesimpulan awal yang dikemukakan masih bersifat sementara, dan akan berubah bila tidak ditemukan bukti-bukti yang kuat mendukung pada tahap pengumpulan data berikutnya. Tetapi apabila kesimpulan yang dikemukakan pada tahap awal, didukung oleh bukti-bukti yang valid dan konsisten saat peneliti kembali kelapangan mengumpulkan data, maka kesimpulan yang dikemukakan merupakan yang kredibel.

\section{HASIL DAN PEMBAHASAN}

\section{Peran Dinas Pariwisata Dalam Tata Kelola Pengembangan Wisata Pantai Mampie}

Dalam arti tertentu,status dan peran adalah dua aspek dari gejala yang sama.Pada umumnya peran dapat diartikan sebagai sesuatu yang menjadi bagian atau pemegang kedudukan yang utama dalam terjadinya sesuatu hal, kegiatan ataupun peristiwa dalam kehidupan kemasyarakatan berdasarkan norma atau peraturan tertentu. Menurut Rivai (2006:148). Dinas Pemuda Olahraga dan Pariwisata sebagai salah satu dinas yang terletak di Kabupaten Polewali Mandar yang bertugas untuk penyelenggara urusan pemerintah daerah serta pembantuan dibidang olahraga dan pariwisata. Sesuai dengan tugas dan fungsinya, dinas ini memiliki peranan yang besar khususnya dalam sektor pariwisata di Kabupaten Polewali Mandar.Dinas pemuda olahraga dan pariwisata dituntut untuk terus melakukan inovasi terkait dengan pen gembangan pariwisata di daerah Kabupaten Polewali Mandar. Pada dasarnya kegiatan pengembangan potensi pariwisata yang diselenggarakan oleh 
Dinas Pemuda Olahraga dan Pariwisata Kabupaten Polewali Mandar diwijudkan melalui dua bagian, yang pertama adalah pada bagian pengembangan potensi pariwisata itu sendiri, serta bagian pemasaran dan promosi wisata. Masing-masing bagian ini memiliki peranannya tersendiri dalam hal pengembangan potensi pariwisata di Kabupaten Polewali Mandar. Bagian pengembangan wisata memiliki peran dan kewajiban untuk mengakomodir sarana dan prasarana diseluruh objek wisata dan usaha wisata yang terdapat di Kabupaten Polewali Mandar, seperti penyediaan akses menuju objek wisata, penyediaan toilet, penyediaan loket dan karcis retribusi masuk objek wisata dan lain sebagainya, sedangkan bagian pemasaran dan promosi wisata secara garis besar berperan dalam rangka mempromosikan objek-objek wisata yang terdapat di Kabupaten Polewali Mandar kepada wisatawan melalui berbagai program yang telah disusun sebelumnya.

Berdasarkan observasi yang dilakukan dan ditambah pula oleh hasil wawancara terstruktur, dapat dianalisa bahwa peran dinasPemuda Olahraga dan pariwisata dalam mengatasi masalah dan kendala harus mengoptimalkan obyek wisata ini kendalanya ialah dari fasilitas dan dana ini harus bekerjasama dengan pihak-pihak yang terkait. Dinas Pemuda Olahraga dan Pariwisata juga memiliki strategi pengembangan dan mengoptimalkan wisata Pantai Mampie ini, Mengevaluasi apa saja yang terdapat masalah dalam mengoptimakan wisata ini Peran Dinas Pariwisata yang mengakordinir dan mengevaluasi setiap permasaalahan. Untuk itu masyarakat juga ikut berpartisipasi dalam mengembangkan dan mewujudkan wisata ini

\section{Dinas Pariwisata dalam Strategi pengembangan Wisata di Pantai Mampie}

Salah satu pantai yang sering menjadi pilihan banyak wisatawan untuk dikunjungi selain pariwisata pantai.Pantai Mampie para wisatawan juga disajikan dengan berbagai wisata lain seperti Wisata Rumah Penyu dan Hutan Mangrove sehingga para wisatawan yang berkunjung tentunya akan tidak akan cepat bosan. Wisatawan yang berkunjung tentunya akan membawa dampak yang baik bagi akeberlanjutan pengembangan pantai Mampie.

Pihak pengelola Pantai Mampie telah merencanakan berbagai strategi pengembangan upaya peningkatan kunjungan wisatawanpantai Mampie.Strategi yang dilakukan dalam pengembangan adalah untuk meningkatkan sumber daya manusia, penambahan sarana dan prasaran, serta kegiatan promosi yang dilakukan diberbagai media sosial. Berikut strategi yang dilakukan dalam upaya pengembangan wisata mampie 
a. Kordinasi

kordinasi ini menjadi keputusan oleh pihak dinas pariwisata dalam mempromosikan objek wisata di Pantai Mampie dan jalinan kerja sama semacam ini terus diorganisir perkembangannya seperti keputusan untuk menjalin kordinasi dari berbagai pihak menjadi keputusan yang harus ditempuh pihak dinas pariwisata dalam mempromosikan objek wisata sistem kordinasi menjadi sarana penting bagi dinas pariwisata kordinasi berjalan dengan baik maka peran dinas Pemuda Olahraga dan Pariwisata sudah terbilang sukses menjalin kerja sama untuk lebih meningkantkan promosi objek wisata kordinasi tersebut harus dibina dalam setiap aparatur dinas pariwisata, terbinanya sistem kordinasi ini dapat menjadikan kunci kesuksesan kordinasi tersebut harus dibina dalam setiap aparatur Dinas Pemuda Olahraga dan Pariwisata untuk mempromosikan objek-objek wisata yang ada di Polewali Mandar, sejauh ini peran dinas dalam kordinasi sangat baik karena dapat menjalin suatu sistem kerja sama dangan berbagai pihak untuk turut serta mempromosikan objek wisata.

b. Promosi Wisata

Promosi dalam stategi pengelolaan dan pengembangan tentunya tidak terlepas dengan adanya promosi semakin canggihnya teknologi dijaman sekarang, memudahkan kita untuk menyebar Informasi hanya dengan melalui media sosial mengenalkan Pantai Mampie dengan menggnakan promosi melalui media hal ini disebutkan oleh masyarakat pengguna media internet. Hal ini disambut baik oleh masyarakat pengguna media sosial yang berkunjung dipantai mampie dan mengetahui Pantai mampie malalui media internet media internet yang digunakan sebagai promosi yaitu melalui Facebook, Instagram dan blog.

c. Pengembangan

Pengelolaan dan pengembangan tempat pariwisata strategis Pantai Mampie yang pertama adalah strategi pengelola pengembangan Wisata Pantai.Dalam pengembangan yang telah dilakukan salah satunya dengan pemanfaatan lahan kosong untuk untuk dikelola dalam penambahan beberapa wisata baru seperti Rumah Penyu dan ditanami dengan banyak pohon mangrove.Menjadikan wisata Pantai mampie terus dikunjungi oleh wisatawan.Dalam pengembangan pariwisata, peranan Pemerintah Daerah sebagai motivator diperlukan agar geliat usaha pariwisata terus berjalan.Investor, masyarakat, serta pengusaha di bidang Pariwisata merupakan sasaran utama yang perlu untuk terus diberikan motivasi agar perkembangan pariwisata dapat berjalan dengan baik.

d. Pembinaan 
Dinas Pemuda Olahraga dan Pariwisata Kabupaten Polewali Mandar senantiasa melakukan sosialisasi dan pembinaan dalam upaya pelestarian wisata Pantai Mampie. Sosialisasi dilakukakn pada masyarakat Desa Galeso untuk membuka pemahaman serta pola pikir masyarakat bahwa betapa pentingnya upaya pelestarian wisata Pantai mampie. Masyarakat yang paham dan mengerti akan membantu realisasi program y ang diimplementasikan oleh Dinas Pemuda Olahraga dan Pariwisata Kabupaten Polewali Mandar melakukan pembinaan kepada masyarakat di sekitar Pantai Mampie tetap konsisten dalam mengembangkan, menjaga serta melestarikan Pantai Mampie. Pembinaan tidak hanya sekedar sampai pada pengelola Pantai Mampie saja, Dinas Pemuda Olahraga dan Pariwisata Kabupaten Polewali Mandar berharap agar penelola juga melakukan pendekatan serta sosialisasi pada masyarakat tentang upaya pelestarian wisata pantai mampie.

e. Pemerataan

pembangunan bertujuan untuk meningkatkan kualitas jaringan jalan, menyediakan sarana transportasi umum dan sarana untuk kendaraan tidak bermotor di lokasi program, serta memperbaiki akses terhadap pelayanan dasar dan infrastruktur yang penting bagi kepuasan wisatawan untuk menikmati pengalaman berwisata. Pembiayaan transportasi jalan untuk meningkatkan kualitas dan kondisi jalan yang terkait dengan pariwisata, termasuk jembatan, melalui konstruksi, pelebaran, perbaikan, rekonstruksi, rehabilitasi, dan perawatan, untuk memenuhi standar dan target.Infrastruktur dan layanan pariwisata, seperti sarana pejalan kaki dan kendaraan tidak bermotor, pembangunan taman dan ruang terbuka hijau, pembangunan dan peningkatan fasilitas angkutan umum. Pelayanan infrastruktur dasar, seperti penyediaan air minum, pengelolaan sampah, pengelolaan air limbah dan sanitasi di kawasan inti pariwisata.

f. Kemitraan

Dalam membangun kemitraan dengan pihak swasta lainnya,maka diperlukan upaya pengembangan dan penguatan terhadap informasi dan data base sebagai data awal potensi keindahan pantai yang ada dimampie sebagai bahan kajian untuk pemerintah dan mitranya terhadapat pengembangan objek wisata. Pada dasarnya programprogram yang dilaksanakan Dinas Pariwisata Kabupaten Polewali Mandar mendukung program-program sektor lain dalam rangkaian peningkatan kesejahteraan masyarakat lahir dan batin. Kebehasilan pembangunan pariwisata akan mempunyai multiplier effect yang menguntungkan semua sektor pembangunan. 
g. Penyelenggaraan

Pariwisata adalah berbagai macam kegiatan wisata yang didukung oleh fasilitas serta layanan yang disediakan oleh masyarakat, pengusaha dan pemerintah daerah. Dalam penyelenggaraan kepariwisataan harusla di dasarkan pada kondisi dan daya dukung dengan maksud menciptakan interaksi jangka panjang yang saling menguntungkan di antara pencapaian tujuan pengembangan pariwisata, kesejahteraan masyarakat setempat, dan berkelanjutan adanya kegiatan pariwisata disuatu tempat berimplikasi pada kebutuhan akan sarana dan prasarana penunjang y ang bervariasi baikjenis maupun bentuk konstruksi fisiknya tergantung pada sumber daya jenis kegiatan wisata yang dikembangankan. Sarana dan prasarana penunjang diadakan untuk memenuhi kebutuhan wisatawan selama mereka tinggal dan berwista di suatu daerah tujuan wisata tertentu termasuk kebutuhsn makan dan tempat tidur dan hal-hal mendasar lainnya. Fasilitas yang disediakan mencakup akomodasi, rumah makan, transportasi dan beberapa fasilitas umum lainnya yang terkait langsung dengan wisatawan.

h. Pengelolaan Sapta Pesona

Sapta Pesona merupakan kondisi yang harus diwujudkan dalam rangka menarik minat wisatawan berkunjung kepantai mampie. Sapta pesona dan tujuan pelaksanaan begitu luas dan untuk kepentingan pariwisata semata.Perencanaan sapta pesona di objek wisata pantai mampie adalah untuk menjadikan pantatai mampie sebagai wisata bahari yang menarik. Sasarannya khusus untuk wisatawan, masyarakat sekitar, dan pelaku usaha.Biaya pengelolaan berasal dari Dinas Pariwisata dan Kelomok Sadar Wisata. Rencana pelaksanaan dengan menjaga keamanan, keberishan, ketertiban, keindahan dan sopan santu, Yang bertujuan untuk meningkatkan kesadaran rasa tanggung jawab segenap lapisan masyarakat pada umumnya untuk bertindak dan mewujudkannya dalam kehidupan sehari-hari dengan harap setiap wisatawan yang berkunjung kepantai mampien memperolah kenangan yangng menyenangkan baik dari objek wisata sendiri maupun dari masyarakat kabupaten polewali mandar.

\section{Analisis Faktor internal dan Eksternal}

Dari hasil analisis lingkungan strategis dapat diidentifikasikan mengenai kekuatan dan kelemahan yang berasal dari lingkungan internal organisasi serta peluang dan ancaman yang berasal dari lingkungan eksternal organisasi peluang dan kekuatan merupakan faktor pendukung sedangkan ancaman dan kelemahan merupakan faktor penghambat perkembangan kepariwisataan 
Peran Dinas Pariwisata Dalam Tata Kelola Pengembangan Wisata Pantai Mampie Untuk Meningkatkan Kesejahteraan Masyarakat Di Kecamatan Wonomulyo Desa Galeso Kabupaten Polewali Mandar

\section{a. Faktor internal}

Merupaka sumberdaya objek yang akan menentukan kekuatan dan kelemahan objek wisata. Sumber daya objek wisata ini meliputi sumber daya Manusia seperti pengalaman, kemampuan, pengetahuan, keahlian, dan pertimbangan.Faktor internal adalah faktor-faktor berupa daya tarik wisata yang meliputi kekuatan dan kelemahan dalam menarik wisatawan di objek wisata Pantai Mampie analisis faktor internal yang meliputi kekuatan dan kelemahan dilakukan untuk mengetahui kondisi daerah tersebut secara internal lingkungan internal merupakan lingkungan yang sangat berpengaruh dan menentukan terhadap penentuan strategi yang akan diformulasikan.

\section{b. Faktor eksternal}

Adalah faktor-faktor yang berupa daya tarik wisata yang meliputi peluang dan ancaman dalam menarik wisatawan di abjek wisata Pantai Mampie.Analisi eksternal yang meliputi peluang dan ancaman dilakukan untuk mengetahui posisi daerah dalam berhadapan dengan lingkungan eksternalnya lingkungan jauh atau lingkungan eksternal merupakan lingkungan yang berada di luar kendali perusahaan. Yang termasuk lingkungan jauh atau eksternal adalah ekonomi sosial, politik, teknologi, dan ekologi..

\section{KESIMPULAN}

Pemerintah berperan sebagai motivator yang mendorong masyarakat untuk bergerak mengembangkan potensi wisata Pantai Mampie, sebagai objek wisata pantai mampie yang potensional.Motivasi dirasa perlu karena masyarakat harus didorong supaya lebih mengerti kemana arah pembangunan dan pengembangan objek wisata alam tersebut.Dalam konteks ini, Dinas Pemuda Olahraga dan Pariwisata juga menjalankan peran dan fungsionalnya yang kedua, yaitu sebagai komunikator. Ketika terdapat komunikasi dan hubungan timbal balik antara dua pihak dua pihak yang saling menguntungkan, Dinas Pemuda Olahraga dan Pariwisata melanjutkan perannya yang ketiga, yaitu sebagai fasilisator dalam konteks ini, Dinas Pemuda Olahraga dan Pariwisata Polewali Mandar sebagai fasilisator dalam melakukan pendampingan berusaha memberikan pengarahan kepada masy arakat tentang penggunaan teknis strategi dan pelaksanaan dalam program yang bermanfaat bagi pengembangan potensi Pantai Mampie.

\section{SARAN}

Volume 1, Nomor 2, April 2017 
Pengembangan daerah Pantai Mampie hendaknya dimulai pembenahan dari segi internal terlebih dahulu seperti peningkatan objek daya tarik, aksesbilitas, amenitas, fasilitas pengunjung dan kelembagaan setelah itu segi eksternalnya berupa pemasran. Pengembangan wisata Pantai Mampie harus ditingkatkan agar wisatawan kembali berkunjung. Meningkatnya kehidupan sosial ekonomi masyarakat wisata Pantai Mampie diharapkan mampu meningkatkan image promotion sebagai tuan rumah menajaga dan meningkatkan pelayanan dalam pengelolaan wisata Pantai Mampie.

\section{DAFTAR PUSTAKA}

Burhan Bungin.2006. Analisis Data Penelitian Kualitatif.Jakarta : Raja Grafindo.

Idastin, Strategi Promosi Wisata Pada Dinas Pariwisata Kabupaten Mamasa. Prodi Ilmu Pemerintahan, Fakultas Ilmu Sosial dan Ilmu Pemerintahan Universitas Al Asyariah Mandar

Rivai, Veithzal. 2006. Kepemimpinan dan Perilaku Organisasi. Jakarta : Raja Grafindo Persada.

Sinaga, (2010:12) Potensi dan Pengembangan objek wisata di kabupaten

Tapanuli Tengah. Kertas Karya. Program DIII Pariwisata. Universitas Sumatera Utara.

Sugiyono. 2007. Metode Penelitian Kuantitatif Kualitatif dan R\&D. Bandung: Alfabeta.

Undang-Undang Nomor 10 Tahun 2009 Tentang Kepariwisataan 